(c) American Dairy Science Association, 2006.

\title{
Comparative Study on Shelf Life of Whole Milk Processed by High-Intensity Pulsed Electric Field or Heat Treatment
}

\author{
I. Odriozola-Serrano, S. Bendicho-Porta, and O. Martín-Belloso' \\ Department of Food Technology UTPV-CeRTA, University of Lleida Rovira Roure 191, 25198 Lleida, Spain
}

\begin{abstract}
The effect of high-intensity pulsed electric fields (HIPEF) processing $(35.5 \mathrm{kV} / \mathrm{cm}$ for 1,000 or $300 \mu \mathrm{s}$ with bipolar $7-\mu$ s pulses at $111 \mathrm{~Hz}$; the temperature outside the chamber was always $<40^{\circ} \mathrm{C}$ ) on microbial shelf life and quality-related parameters of whole milk were investigated and compared with traditional heat pasteurization $\left(75^{\circ} \mathrm{C}\right.$ for $\left.15 \mathrm{~s}\right)$, and to raw milk during storage at $4^{\circ} \mathrm{C}$. A HIPEF treatment of $1,000 \mu \mathrm{s}$ ensured the microbiological stability of whole milk stored for $5 \mathrm{~d}$ under refrigeration. Initial acidity values, $\mathrm{pH}$, and free fatty acid content were not affected by the treatments; and no proteolysis and lipolysis were observed during 1 wk of storage in milk treated by HIPEF for 1,000 $\mu \mathrm{s}$. The whey proteins (serum albumin, $\beta$-lactoglobulin, and $\alpha$-lactalbumin) in HIPEF-treated milk were retained at $75.5,79.9$, and $60 \%$, respectively, similar to values for milk treated by traditional heat pasteurization.
\end{abstract}

Key words: high-intensity pulsed electric field, whole milk, shelf life

\section{INTRODUCTION}

Milk as a raw material has a relatively short shelf life. However, it can be processed by heat treatment to extend its shelf life. Such thermal processes not only destroy microorganisms, but also cause substantial changes in the nutritional, organoleptic, or technological properties of milk. In addition, milk may slowly deteriorate from the effect of the residual activity of enzymes such as lipases and proteases. Although most psychrotrophs are destroyed by pasteurization, many species produce heat-stable lipase and protease enzymes, which retain activity after pasteurization (Cogan, 1977). Celestino et al. (1997) showed an increase in numbers of lipolytic and proteolytic bacteria and dominance of psychrotrophs after storage of raw milk at refrigeration temperature $\left(4 \pm 1^{\circ} \mathrm{C}\right)$ for $2 \mathrm{~d}$. The in-

Received August 16, 2005.

Accepted November 2, 2005

${ }^{1}$ Corresponding author: Omartin@tecal.udl.es creasing demand for fresh-like and nutritious products has raised the concern of the food industry for the development of milder preservation technologies to replace existing pasteurization methods. Because some milk components are unstable to heat, nonthermal technologies would be suitable for processing milk while avoiding adverse effects on flavor and nutrients. Among these technologies, high-intensity pulsed electric fields (HIPEF) can achieve high inactivation levels of spoilage and pathogenic microorganisms that can grow in milk with minimal impact on quality and nutrition factors (Sampedro et al., 2005). Most of the studies carried out with milk have been performed to evaluate the effect of HIPEF on microbial inactivation. The level of destruction achieved with HIPEF treatment depends mainly on the field's strength and the number of pulses applied during the process (Martín et al., 1997). Pasteurized milk inoculated with Escherichia coli, Salmonella Dublin, Listeria innocua, Pseudomonas fluorescens, and Bacillus cereus has been subjected to HIPEF treatment. In these studies, it was proved that HIPEF is efficient in the inactivation of the microorganisms, accomplishing a 2 to $4 \log$ reduction. The effect of HIPEF treatment of raw milk has also been studied. After processing raw skim milk by HIPEF, it was observed that some microorganisms were resistant to the HIPEF treatment, including Corynebacterium spp. and Xanthomas malthophilia (Bendicho et al., 2002b).

Qin et al. (1995) observed that raw milk treated by HIPEF $(40 \mathrm{kV} / \mathrm{cm})$ and stored under refrigeration had a microbial shelf life of $2 \mathrm{wk}$. However, the shelf life of HIPEF-processed milk depends on the initial concentration of these HIPEF-resistant microorganisms as well as on their ability to grow at refrigeration temperatures (Raso et al., 1998).

Compared with the extensive research devoted to the destruction of microorganisms by HIPEF, there are few studies about the inactivation of enzymes by HIPEF in milk. The studied enzymes were protease from $P$. fluorescens (Vega-Mercado et al., 2001) and Bacillus subtilis (Bendicho et al., 2003a,b, 2005), and alkaline phosphatase (Van Loey et al., 2002) and lipase from $P$. fluorescens (Bendicho et al., 2002a). However, it has been observed that, in general, enzymes require more 
severe HIPEF treatment than microorganisms to obtain significant inactivation (Bendicho et al., 2002a, $2003 a, b)$. Variation in enzyme activity depends on the electric field intensity, treatment length, treatment temperature, HIPEF characteristics, type of enzyme, enzyme concentration, and the media containing the enzyme (Vega-Mercado et al., 2001). Other studies have focused on changes in organoleptic and physiochemical characteristics in milk that has undergone HIPEF treatments.

Dunn (1995) studied enzyme activity, fat integrity, starter growth, rennet clotting yield, cheese production, calcium distribution, casein structure, and protein integrity in raw milk treated with HIPEF at 20 to 80 $\mathrm{kV} / \mathrm{cm}$ for 1 to $10 \mu \mathrm{s}$. The authors concluded that no significant changes were observed in the studied parameters, and suggested making cheese, butter, and ice cream with treated milk to obtain products with organoleptic characteristics similar to fresh products. On the other hand, Qin et al. (1995) carried out a study of physicochemical properties and sensory attributes of milk with $2 \%$ milk fat treated by HIPEF $(40 \mathrm{kV} / \mathrm{cm})$. They observed no physicochemical or sensory changes after treatment compared with samples treated by thermal pasteurization. Finally, Michalac et al. (2003) studied variation in color, $\mathrm{pH}$, proteins, moisture, and particle size of UHT skim milk subjected to HIPEF treatment set to $35 \mathrm{kV} / \mathrm{cm}$ for $188 \mu \mathrm{s}$. The authors saw no differences in the parameters studied before and after treatments. However, no reports about the effect of HI$\mathrm{PEF}$ on fats and proteins in whole milk have been found in the literature. Published reports have not described the evolution of these compounds through their shelf life after HIPEF treatment.

The HIPEF conditions selected for this study were similar to those used to achieve a high degree of enzyme inactivation (Bendicho et al., 2002a, 2003a,b, 2005), which are more severe than those effective in the destruction of microorganisms (Sobrino et al., 2001). The aim of this work was to evaluate the effect of the HIPEF treatment adequate to destroy microorganisms and enzymes on some physicochemical and microbiological changes that occur during storage of milk. A comparative study was carried out among HIPEF-treated, thermally pasteurized, and fresh milk.

\section{MATERIALS AND METHODS}

\section{Sample Preparation}

This study was performed in whole raw milk (3.6\% fat) provided by Granja Castelló S.A. (Mollerussa, Spain). Milk was kept refrigerated for up to $2 \mathrm{~h}$ before
Table 1. Studied parameters of whole milk before treatment

\begin{tabular}{lr}
\hline Parameter & \multicolumn{1}{c}{ Value $^{1}$} \\
\hline Aerobic count $[\log (\mathrm{cfu} / \mathrm{mL})]$ & $3.2 \pm 0.03$ \\
$\mathrm{pH}$ & $6.80 \pm 0.01$ \\
Acidity (g of lactic acid/100 mL of milk) & $0.142 \pm 0.001$ \\
Concentration of FFA $(\mathrm{mEq} / 100 \mathrm{~g}$ of fats) & $0.95 \pm 0.01$ \\
\hline
\end{tabular}

${ }^{1}$ Values are mean $\pm \mathrm{SE}$.

processing. The studied parameters before treatment are summarized in Table 1.

\section{Thermal Treatment}

A thermal pasteurization $\left(75^{\circ} \mathrm{C}\right.$ for $\left.15 \mathrm{~s}\right)$ was applied to use as a reference value to compare the effectiveness of HIPEF treatments on microorganism level, fat content, and different fractions of whey proteins. Milk was thermally processed in a tubular heat exchanger. A gear pump was used to maintain the milk flow rate through a stainless steel heat exchange coil, which was immersed in a shaking boiling water bath. After thermal processing, the milk was immediately cooled in a heat exchange coil, which was immersed in an ice water bath.

\section{Pulsed Electric Field Treatment}

Pulse treatments were carried out using a continuous flow bench scale system (OSU-4F, Ohio State University, Columbus, $\mathrm{OH}$ ) that held positive monopolar squared-wave pulses. The treatment chamber device consisted of 8 colinear chambers arranged in series; each chamber contained 2 stainless steel electrodes separated by a gap of $0.29 \mathrm{~cm}$. Each chamber had a treatment volume of $0.012 \mathrm{~cm}^{3}$.

The treatment flow rate was $60 \mathrm{~mL} / \mathrm{min}$, and was controlled by a variable speed pump (model 752210-25, Cole Palmer Instrument Company, Vermon Hills, IL). The product was refrigerated in the space provided between the chambers by means of iced water. The final temperature never exceeded $40^{\circ} \mathrm{C}$.

Samples were subjected to a field strength of 35.5 $\mathrm{kV} / \mathrm{cm}$ for 300 or $1,000 \mu \mathrm{s}$. Each pulse lasted $7 \mu \mathrm{s}$, and the pulse repetition rate was set at $111 \mathrm{~Hz}$.

\section{Aerobic Plate Count}

Serial dilutions of untreated and treated samples (10 $\mathrm{mL}$ ) were prepared with $90 \mathrm{~mL}$ of $1 \%$ sterile peptone solution. One milliliter of each diluted sample was plated on plate count agar and incubated at $30^{\circ} \mathrm{C}$ for $72 \mathrm{~h}$. 


\section{Determination of $\mathrm{pH}$ and Total Acidity}

The $\mathrm{pH}$ was measured using a $\mathrm{pH}$ meter (Crison Instruments SA, Alella, Barcelona, Spain). Total acidity was determined by titration with $0.1 \mathrm{M} \mathrm{NaOH}$.

\section{Free Fatty Acids}

A solvent mixture comprising isopropanol, petroleum ether, and $4 N$ sulfuric acid (40:10:1) was prepared by the method described by Deeth et al. (1975). Fifteen milliliters of whole milk was added to $20 \mathrm{~mL}$ of solvent mixture. After mixing, a further $12 \mathrm{~mL}$ of petroleum ether and $8 \mathrm{~mL}$ of distilled water were added. Then, the mixture was decanted to separate it into 2 phases. The fat and FFA were collected together in the upper phase, and the acidity of the combined supernatants was titrated with ethanol solution of $0.001 \mathrm{M} \mathrm{KOH}$.

\section{Quantitative Fraction of Whey Proteins}

Preparation of Casein and Whey Protein Fractions. Raw milk samples were centrifuged at 5,300 $\times$ $g$ for $20 \mathrm{~min}$ in a refrigerated centrifuge to remove fat. The proteins were obtained by acidifying milk to $\mathrm{pH}$ 4.6 by the slow addition of $1 \mathrm{~mL}$ of $10 \%$ acetic acid and $1 \mathrm{~mL}$ of $1 M$ sodium acetate to $5 \mathrm{~mL}$ of cold skim milk; the mixture was heated at $40^{\circ} \mathrm{C}$ for $30 \mathrm{~min}$, and then centrifuged at $14,000 \times g$ for $30 \mathrm{~min}$. The whey proteins were analyzed by gel electrophoresis.

Electrophoresis. The whey proteins were mixed with glycerol $40 \%$ and bromophenol blue. The polyacrylamide gel was prepared following the method of Hillier (1976). Electrophoresis was carried out for $250 \mathrm{~min}$ at $80 \mathrm{~V}$. Gels were stained for $1 \mathrm{~h}$ with Coomassie Blue, then destained in a solvent with ethanol/glacial acetic/ water solvent (25:10:65). Electrodes were immersed in a buffer solution at $\mathrm{pH}$ 8.5. The concentration of serum albumin, $\alpha$-LA, and $\beta$-LG in the milk sample preparations were determined by comparing the band intensities of the whey proteins in the milk samples with standards made with $0.023 \%$ serum albumin, $0.042 \% \alpha$-LA, $0.40 \% \beta$-LG A, and $0.042 \% \beta$-LG B in buffer solution at $\mathrm{pH} 7$.

\section{Statistical Analyses}

Significance of the results and statistical differences were analyzed using the Statgraphics Plus v.5.1 Windows package (Statistical Graphics Co., Rockville, MD). The ANOVA was performed to compare treatment mean values. The least significant difference test was used to determine differences between means at the $5 \%$ significance level. Correlations among population

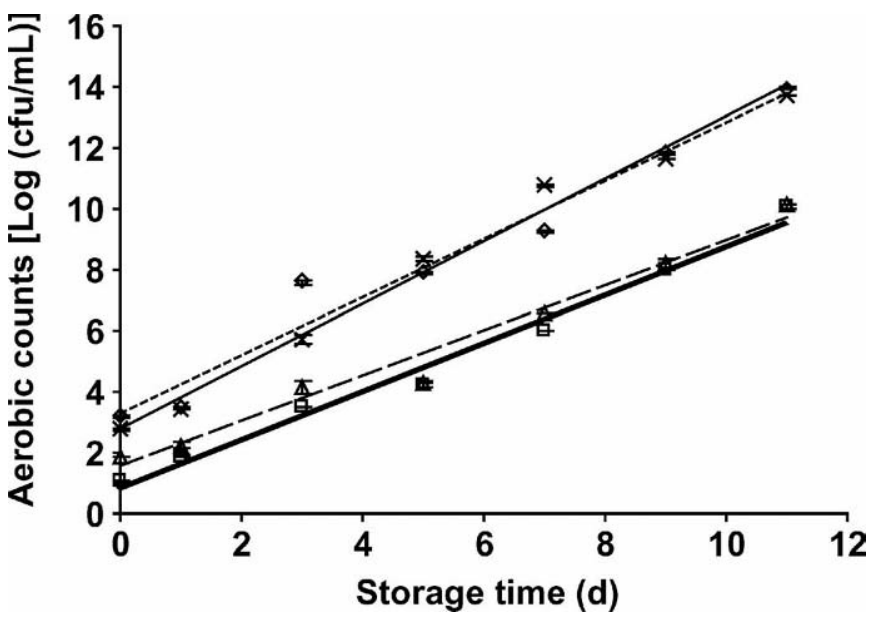

Figure 1. Effects of high-intensity pulsed electric field (HIPEF) treatment and heat pasteurization on total aerobic bacteria of whole milk throughout storage at $4^{\circ} \mathrm{C}$. Type of milk treatment: untreated $(\diamond)$, heat pasteurization $(\square)$, HIPEF for $1,000 \mu \mathrm{s}(\Delta)$, and HIPEF for $300 \mu \mathrm{s}(\times)$.

of mesophilic microorganisms and $\mathrm{pH}$, total acidity, and fats were evaluated with Pearson's test.

\section{RESULTS AND DISCUSSION}

\section{Microbial Stability and Shelf Life}

Initial populations of mesophilic aerobic microorganisms in fresh milk were approximately $3.2 \log (\mathrm{cfu} / \mathrm{mL})$. Less than 1 log reduction in initial microflora was observed following HIPEF treatment at $35.5 \mathrm{kV}$ for 300 $\mu \mathrm{s}$. However, significant inactivation levels were achieved with HIPEF treatment at $35.5 \mathrm{kV}$ for 1,000 $\mu \mathrm{s}$, as well as through thermal treatment. These treatments led to $\sim 1$ and 2 log cycle reductions, respectively. Several authors reported significant inactivation levels on microorganisms after similar or milder treatments to those evaluated in this study. Raso et al. (1999) reported that Staphylococcus aureus and CNS could be reduced by 4 and 2 log cycles, respectively, after 40 pulses at $40 \mathrm{kV}$ and $3.5 \mathrm{~Hz}$ in skim milk. On the other hand, Calderón-Miranda et al. (1999) achieved reductions from 1.5 to $2 \log$ of L. innocua in skim milk by applying similar treatment conditions. Martín et al. (1997) found that HIPEF treatment inactivated Escherichia coli in skim milk up to 2 log reductions after 25 pulses at $25 \mathrm{kV} /$ $\mathrm{cm}$. Sensoy et al. (1997) reported near $4 \mathrm{log}$ reductions in Salmonella Dublin after a treatment of $30 \mathrm{kV} / \mathrm{cm}$ and $163.9 \mu \mathrm{s}$.

Mesophilic aerobic counts increased without significant differences between milk treated by HIPEF for $1,000 \mu \mathrm{s}$ and thermally pasteurized milk (Figure 1). As can be seen, the aerobic bacteria rapidly increased 


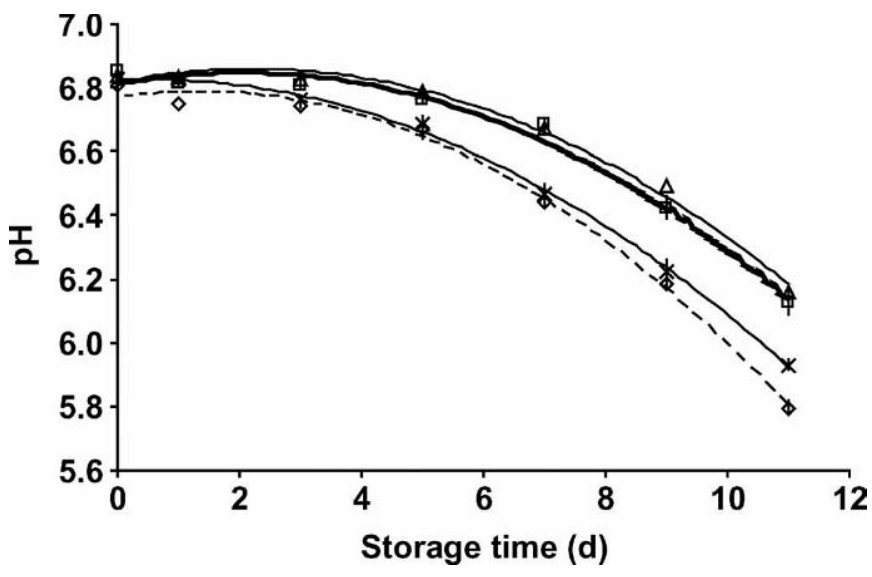

Figure 2. Effects of high-intensity pulsed electric field (HIPEF) treatment and heat pasteurization on $\mathrm{pH}$ of whole milk throughout storage at $4^{\circ} \mathrm{C}$. Type of milk treatment: untreated $(\diamond)$, heat pasteurization ( $\square$ ), HIPEF for $1,000 \mu \mathrm{S}(\Delta)$, and HIPEF for $300 \mu \mathrm{S}(\times)$.

during the storage period. Milk with $2 \times 10^{4}$ total mesophilic bacteria was considered to be at the end of its shelf life, as defined in the pasteurized milk ordinance for Grade A milk and milk products (HHS/PHS/FDA, 2001). Spoilage of pasteurized milk stored at $4^{\circ} \mathrm{C}$ is commonly caused by gram-negative psychrotrophic bacteria that survive pasteurization in small numbers or contaminate the milk after pasteurization (Richter et al., 1992). Thus, storage conditions led to the development of microorganisms that limited the commercial shelf life of the product. Hence, milk treated by HIPEF for $1,000 \mu \mathrm{s}$ had a shelf life of $5 \mathrm{~d}$. These results are not in agreement with those reported by Qin et al. (1995), in which milk achieved a shelf life of $14 \mathrm{~d}$. However, the temperature increased up to about $55^{\circ} \mathrm{C}$ in the treatment applied by those authors, whereas the temperature in this study never exceeded $40^{\circ} \mathrm{C}$. On the other hand, differences among results should be due to the fat content of the samples. Qin et al. (1995) treated skim milk, whereas this study evaluated whole milk. Goff and Hill (1993) reported that fats protect microorganisms from inactivation. It is more difficult to achieve high levels of destruction of microorganisms when the matrix is complex (Martín et al., 1997). Fats can diminish the lethal effect of HIPEF in microorganisms by absorbing free radicals and ions, which are active in the cell breakdown (Gilliland and Speck, 1967).

\section{Effect of Processing and Storage Conditions on $\mathrm{pH}$ and Acidity}

Values of $\mathrm{pH}$ and acidity for HIPEF treatment, thermal pasteurized and untreated whole milk are shown in Figures 2 and 3. The type of processing had no sig-

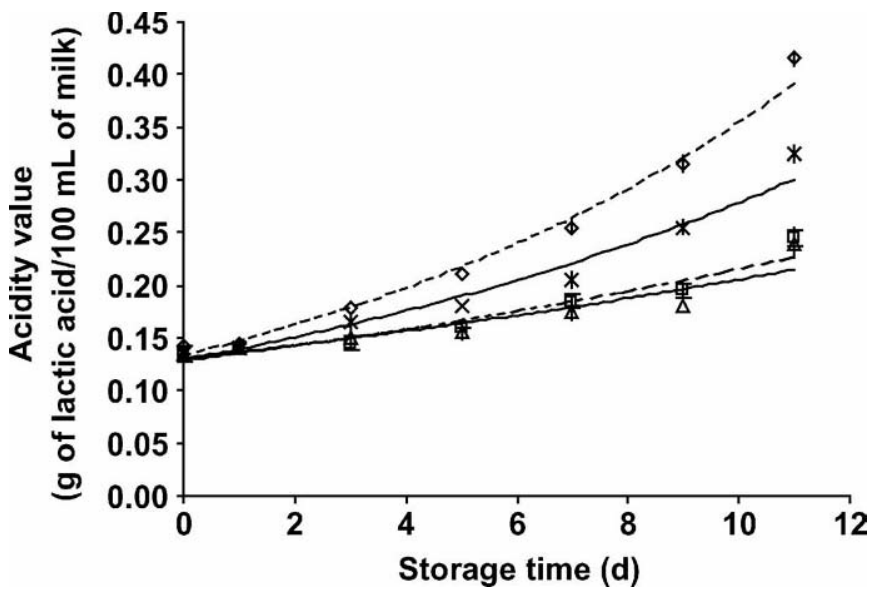

Figure 3. Effects of high-intensity pulsed electric field (HIPEF) treatment and heat pasteurization on acidity values of whole milk throughout storage at $4^{\circ} \mathrm{C}$. Type of milk treatment: untreated $(\diamond)$, heat pasteurization ( $\square$ ), HIPEF for $1,000 \mu \mathrm{S}(\Delta)$, and HIPEF for 300 $\mu \mathrm{S}(\mathrm{X})$.

nificant effect $(P<0.05)$ on the physical properties of milk immediately after the treatment. However, acidity and $\mathrm{pH}$ values for untreated milk were $0.142 \mathrm{~g}$ of lactic acid/100 mL of milk and 6.80, respectively, showing significant differences between treated and untreated samples. These results are in agreement with those of other authors. Walstra et al. (1999) reported a pH of 6.6 to 6.8 for milk from healthy cows.

On the other hand, the $\mathrm{pH}$ of the product decreased slightly throughout storage from a range of 6.83 to 6.85 to values of 5.93 to 6.16 at $11 \mathrm{~d}$ for treated milk. This resulted in an increase in acidity throughout storage that may be due to the spoilage of milk by microorganisms that would contribute to an increase in acidity. There is a good correlation of $\mathrm{pH}\left(\mathrm{R}^{2}=0.9087\right)$ and acidity $\left(R^{2}=0.8970\right)$ with concentration of microorganisms. No significant changes were found in the $\mathrm{pH}$ and acidity evolution throughout the storage for thermal and HIPEF $(1,000 \mu \mathrm{s})$ treated milk.

\section{Effect of Processing and Storage Conditions on Fats and Proteins}

As can been seen in Figure 4, neither HIPEF nor thermal treatments affected the FFA content in whole milk, because no significant differences $(P<0.05)$ were found between treated and untreated samples. Kuzdzal-Savoie (1979) reported a free fatty acid content of $0.25 \mathrm{mEq} / 100 \mathrm{~g}$ of fat for untreated whole milk. On the other hand, San José and Juarez (1983) observed between 0.83 and $1.0 \mathrm{mEq} / 100 \mathrm{~g}$ of fat for milk treated by heat pasteurization. These results are in concordance with the results obtained in this work. The 


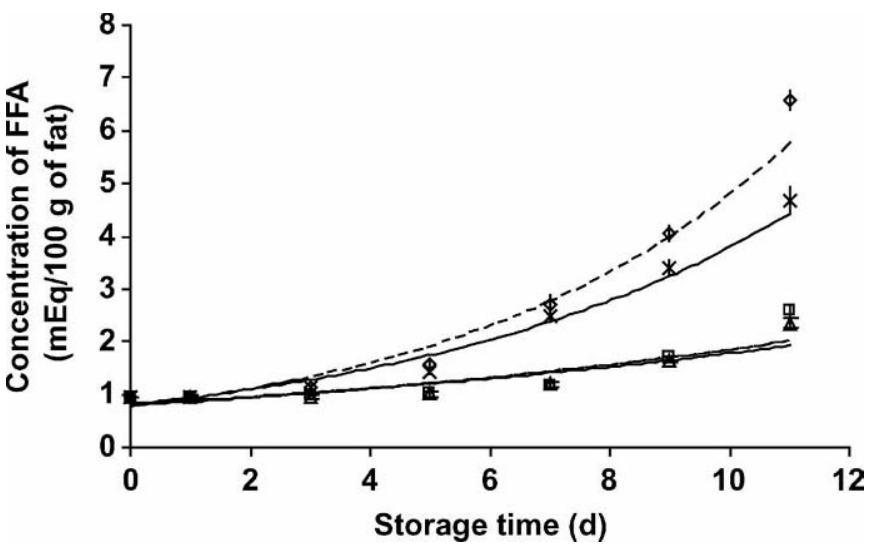

Figure 4. Effects of high-intensity pulsed electric field (HIPEF) treatment and heat pasteurization on FFA content of whole milk throughout storage at $4^{\circ} \mathrm{C}$. Type of milk treatment: untreated $(\diamond)$, heat pasteurization ( $\square$ ), HIPEF for $1,000 \mu \mathrm{s}(\triangle)$, and HIPEF for 300 $\mu \mathrm{s}(\times)$.

method for titration of FFA is an available assay to measure the degree of lipolysis in milk. Bendicho et al. (2002a) reported that lipase from $P$. fluorescens was quite resistant to usual thermal treatments. High $\left(75^{\circ} \mathrm{C}\right.$ for $15 \mathrm{~s})$ and low $\left(63^{\circ} \mathrm{C}\right.$ for $\left.30 \mathrm{~min}\right)$ pasteurization treatments led to inactivations of 5 and $20 \%$, respectively. Other authors have also highlighted the thermoresistance of extracellular enzymes from milk psychrotrophic bacteria. Kishonti (1975) found that, in general, several lipases were able to maintain at least $75 \%$ of their initial activity after a treatment of $63^{\circ} \mathrm{C}$ for 30 min. On the other hand, Bendicho et al. (2002a) achieved inactivation of only $13 \%$ when HIPEF treatments were applied in the continuous-flow mode applying 80 pulses at $37.3 \mathrm{kV} / \mathrm{cm}$ and $3.5 \mathrm{~Hz}$ on lipase from $P$. fluorescens. Ho et al. (1997) studied the effect of HIPEF on a lipase with continuous-flow equipment; its activity was reduced to $85 \%$ after applying 30 pulses at $90 \mathrm{kV} / \mathrm{cm}$.

The content of FFA changed significantly throughout storage. Free fatty acids increased from 0.95 to 2.35 to $6.58 \mathrm{mEq} / 100 \mathrm{~g}$ of fat at the end of storage (Figure 4). The lowest FFA content during storage was achieved in HIPEF-treated (for 1,000 $\mu \mathrm{s}$ ) whole milk. Differences in the fat degradation between HIPEF for 1,000 $\mu \mathrm{s}$ and heat treatments did not appear to be significant $(P<$ 0.05). Nevertheless, a significant increase in the FFA content of untreated and HIPEF-treated (for $300 \mu \mathrm{s}$ ) whole milk was detected from $\mathrm{d} 3$ to 11 , reaching maximum values of $6.58 \mathrm{mEq} / 100 \mathrm{~g}$ of fat for untreated milk. These changes may be related to the spoilage of milk by microorganisms that would contribute to an increase of fat degradation. Milk may contain a variety of microorganisms capable of secreting lipases, which subse-
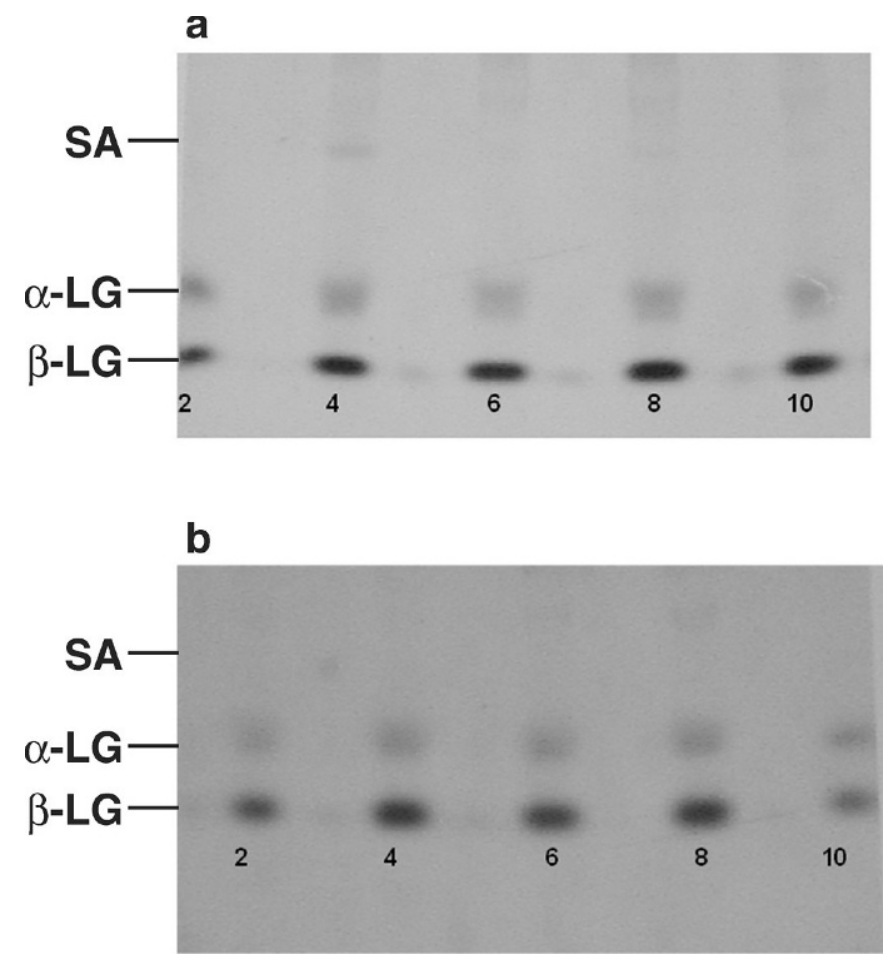

Figure 5. Polyacrylamide gel electrophoresis patterns of proteins present in whole milk (a) after treatment, and (b) after $11 \mathrm{~d}$ of storage. Lane $2=$ heat-pasteurized milk $\left(75^{\circ} \mathrm{C}\right.$ for $\left.15 \mathrm{~s}\right)$; lane $4=$ untreated milk; lane $6=$ milk treated by high-intensity pulsed electric field (HIPEF) for 1,000 $\mu \mathrm{s}$; lane $8=$ milk treated by HIPEF for $300 \mu \mathrm{s}$; and lane $10=$ standard $(0.023 \%$ seroalbumin, $0.042 \% \alpha$-LA, $0.40 \%$ $\beta$-LG A, and $0.042 \% \beta$-LG B); SA = serum albumin.

quently may alter this product. The gram-negative bacteria, in particular, produce extracellular lipases that may remain active after the usual heat treatments applied in the manufacture of dairy products (Driessen, 1983). There is good correlation between populations of mesophilic aerobic microorganisms and the content of FFA $\left(\mathrm{R}^{2}=0.8561\right)$. Muir et al. (1978) observed that lipolysis, which occurs during storage of milk, is correlated with the total count of psychrotrophic bacteria before storage. It has long been known that gram-negative bacteria can produce thermoresistant lipases (Cogan, 1977) and that the lipolytic flora increases during cold storage of raw milk (Muir et al., 1978).

The effects of HIPEF and thermal processing on the concentration of different fractions of whey proteins are illustrated in Figure 5. After treatment, significant differences were found between untreated and HIPEFtreated (for $300 \mu \mathrm{s}$ ) milk, and between HIPEF-treated (for 1,000 $\mu \mathrm{s}$ ) and thermally treated milk for each fraction of whey protein. The $\alpha$-LA, $\beta$-LG, and serum albumin contents in whole milk were $1.18,2.55$, and 0.52 $\mathrm{g} / \mathrm{L}$, respectively. The content of whey protein in whole milk was studied and the results obtained in the present 
work were in the range of published results, which varied from 1 to $1.5 \mathrm{~g} / \mathrm{L}$ for $\alpha$-LA, 2 to $4 \mathrm{~g} / \mathrm{L}$ for $\beta$-LG, and 0.1 to $0.4 \mathrm{~g} / \mathrm{L}$ for serum albumin (Lopez-Fandiño et al., 1992; Robin et al., 1993; Walstra et al., 1999). Nevertheless, no information was found about the effect of HI$\mathrm{PEF}$ on whey protein concentration in milk. The lowest values of whey protein content were observed in milk treated by traditional heat pasteurization. Fox and McSweeney (1998) observed that whey proteins are susceptible to denaturation by various agents, including heat. Whey proteins are relatively heat-labile, and denaturation is accompanied by extensive breaking and randomization of the stabilizing disulfide bonds (Varnam and Sutherland, 1994). Furthermore, in thermal pasteurization, the highest destruction of whey protein fraction was achieved for $\alpha$-LA and the lowest for serum albumin. These results are in agreement with those found by Celestino et al. (1997), who reported that the order of heat stability of the whey protein is $\alpha$-LA $>\beta$ $L G>$ serum albumin. Regarding the destruction of whey protein during storage, untreated and HIPEF-treated (for $300 \mu \mathrm{s}$ ) milk had faster protein destruction than thermal and HIPEF (for 1,000 $\mu \mathrm{s}$ ) treatments. These results could be attributed to an increase in proteolytic activity produced by the microflora of milk. Bendicho et al. (2003a) observed that proteolytic activity increased or decreased significantly depending on the applied HIPEF treatment when the medium was skim milk. Protease activity decreased with increased treatment time, field strength, or pulse rate. The maximum inactivation $(81 \%)$ was attained in skim milk at 35.5 $\mathrm{kV} / \mathrm{cm}$ and $111 \mathrm{~Hz}$ for $866 \mu \mathrm{s}$.

\section{CONCLUSIONS}

High-intensity pulsed electric field processing (35.5 $\mathrm{kV} / \mathrm{cm}$ for $1,000 \mu \mathrm{s}$ with $7-\mu \mathrm{s}$ bipolar pulses at 111 $\mathrm{Hz}$ ) can produce stable whole milk with a shelf life comparable to that of heat-pasteurized milk $\left(75^{\circ} \mathrm{C}\right.$ for $15 \mathrm{~s}$ ). Treating whole milk with HIPEF was as effective as heat pasteurization in terms of microorganisms, enzyme, and physical stability. However, HIPEF (300 $\mu s)$ treatment did not have important effects on the studied parameters. Treatment by HIPEF for $1,000 \mu \mathrm{s}$ extended the shelf life of whole milk to $5 \mathrm{~d}$, a similar result to that achieved with traditional pasteurization.

\section{ACKNOWLEDGMENTS}

The authors thank the Interministerial Comission for Science and Technology (CICYT) of Spain for their support of the work included in the Project ALI 97 0774, and also thank the Agència de Gestió d'Ajuts Universitaris i de Recerca of the Generalitat de Catalu- nya (Spain) for supporting the research grant of Isabel Odriozola.

\section{REFERENCES}

Bendicho, S., G. V. Barbosa-Cánovas, and O. Martín. 2002b. Milk processing by high intensity pulsed electric fields. Trends Food Sci. Technol. 13:195-204.

Bendicho, S., G. V. Barbosa-Cánovas, and O. Martín. 2003a. Reduction of protease activity in milk continuous flow high-intensity pulsed electric field treatment. J. Dairy Sci. 86:697-703.

Bendicho, S., G. V. Barbosa-Cánovas, and O. Martín. 2003b. Reduction of protease activity in simulated milk ultrafiltrate by continuous flow high-intensity pulsed electric field treatment. J. Dairy Sci. 86:952-957.

Bendicho, S., C. Estela, J. Giner, G. V. Barbosa-Cánovas, and O. Martín. 2002a. Effect of high intensity pulsed electric field and thermal treatments on a lipase from Pseudomonas fluorescens. J. Dairy Sci. 85:19-27.

Bendicho, S., A. R. Marsellés-Fontanet, G. V. Barbosa-Cánovas, and O. Martín-Belloso. 2005. High intensity pulsed electric fields and heat treatments applied to a protease from Bacillus subtilis. A comparison study of multiple systems. J. Food Eng. 69:317-323.

Calderón-Miranda, M. L., G. V. Barbosa-Cánovas, and B. G. Swanson. 1999. Inactivation of Listeria innocua in skim milk by pulsed electric fields and nisin. Int. J. Food Microbiol. 51:19-30.

Celestino, E. L., M. Iyer, and H. Roginski. 1997. The effect of refrigerated storage of raw milk on the quality of whole milk powder stored for different periods. Int. Dairy J. 7:119-127.

Cogan, T. M. 1977. A review of heat-resistant lipases and proteinases, and the quality of dairy products. Irish J. Food Sci. Technol. 1:95-105.

Deeth, H. C., C. H. Fitzgerald, and A. F. Wood. 1975. A convenient method for determining the extent of lipolysis in milk. Aust. J. Dairy Technol. 30:109-110.

Driessen, F. M. 1983. Lipases and proteinases in milk. Occurrence, heat inactivation, and their importance for the keeping quality of milk products. Ph.D. Diss., Agricultural University Wageningen, The Netherlands.

Dunn, J. E. 1995. Pulsed light and pulsed electric fields for food and eggs. Poult. Sci. 75:1133-1136.

Fox, P. F., and P. L. H. McSweeney. 1998. Dairy Chemistry and Biochemistry. Department of Food Chemistry, University College, Cork, Ireland. Blackie Academic and Professional, London, UK.

Gilliland, S. E., and M. L. Speck. 1967. Inactivation of microorganisms by electrohydraulic shock. Appl. Microbiol. 15:1031-1037.

Goff, H. D., and A. R. Hill. 1993. Chemistry and Physics. Pages 182 in Dairy Science and Technology Handbook. Principles and Properties. Vol. 1. Y. H. Hui, ed. VCH Publ., New York, NY.

HHS/PHS/FDA. 2001. Grade A pasteurized milk ordinance. Section 7. Standards for grade "A" milk and milk products. US Department of Health and Human Services, Public Health Services, Food and Drug Administration. Center for Food Safety and Applied Nutrition, Rockville, MD.

Hillier, R. M. 1976. The quantitative measurement of whey proteins using polyacrylamide-gel electrophoresis. J. Dairy Res. 43:259265.

Ho, S. Y., G. S. Mittal, and J. D. Cross. 1997. Effects of high electric pulses on the activity of selected enzymes. J. Food Eng. 31:69-84.

Kishonti, E. 1975. Influence of heat resistant lipases and proteases in psycrotrophic bacteria on product quality. Bull. Int. Dairy Fed. 86:122-124.

Kuzdzal-Savoie, S. 1979. Determination of free fatty acids in milk and milk products. Pages 52-66 in IDF Doc. A-43. International Dairy Federation, Brussels, Belgium.

Lopez-Fandiño, R., A. Olano, N. Corzo, and M. Ramos. 1992. Proteolysis during storage of UHT milk. J. Dairy Res. 60:339-347.

Martín, O., B. L. Quin, F. J. Chang, G. V. Barbosa-Cánovas, and B. G. Swanson. 1997. Inactivation of Escherichia coli in skim milk 
by high intensity pulsed electric fields. J. Food Process Eng. 20:317-336.

Michalac, S. L., V. B. Alvarez, and Q. H. Zhang. 2003. Inactivation of selected microorganisms and properties of pulsed electric field processed milk. J. Food Process. Preserv. 27:137-151.

Muir, D. D., M. E. Kelly, J. D. Phillips, and A. G. Wilson. 1978. The quality of blended raw milk in creameries in Southwest Scotland. J. Soc. Dairy Technol. 31:137-144.

Qin, B. L., U. R. Pothakamury, H. Vega, O. Martín, G. V. BarbosaCánovas, and B. G. Swanson. 1995. Food pasteurization using high-intensity pulsed electric fields. Food Technol. 49:55-60.

Raso, J., M. M. Góngora, M. L. Calderón, G. V. Barbosa-Cánovas, and B. G. Swanson. 1998. Resistant microorganisms to high intensity pulsed electric field pasteurization of raw skim milk. IFT Annu. Mtg., Chicago, IL. Institute of Food Technologists, Atlanta, GA.

Richter, R., R. Ledford, and S. Murphy. 1992. Milk and milk products. Pages 837-856 in Compendium of methods for the microbiological examination of foods. 3rd ed. C. Vanderzant and D. Splittstoesser, ed. American Public Health Association, Washington, DC.

Robin, O., S. Turgeon, and P. Paquin. 1993. Functional properties of milk proteins. Pages 277-353 in Dairy Science of Technology Handbook. Vol. 1. Y. H. Hui, ed. VCH Publishers, New York, NY.

Sampedro, F., A. Rodrigo, A. Martínez, and D. Rodrigo. 2005. Quality and safety aspects of PEF application in milk and milk products. Crit. Rev. Food Sci. Nutr. 45:25-47.
San José, C., and M. Juarez. 1983. Lipólisis en leche y productos lácteos. Métodos de control. Alimentación Equipos y Tecnología 4:33-42.

Sensoy, I., Q. Zhang, and S. K. Sastry. 1997. Inactivation kinetics of Salmonella Dublin by pulsed electric fields. J. Food Process Eng. 20:367-381.

Sobrino, A., J. R. Rosell, S. Bendicho, V. Sanchís, and O. Martín. 2001. Inactivation of Staphylococcus aureus and Bacillus cereus in milk by pulsed electric fields and moderate heating. NIZO Dairy Conference on Food Microbes. NIZO Food Research, Ede, The Netherlands.

Van Loey, A., B. Verachtert, and M. Hendrichkx. 2002. Effects of high electric fields pulses on enzymes. Trends Food Sci. Technol. 12:94-102.

Varnam, A. H., and J. P. Sutherland. 1994. Milk and Milk products. Pages 42-88 in Technology Chemistry and Microbiology. Chapman and Hall, London, UK.

Vega-Mercado, H., J. R. Powers, O. Martín-Belloso, L. Luedecke, and G. V. Barbosa-Cánovas, and B. G. Swanson. 2001. Change in susceptibility of proteins to proteolysis and the inactivation of an extracellular protease from Pseudomonas fluorescens M3/6 when exposed to pulsed electric fields. Pages 105-120 in Pulsed Electric Fields in Food Processing. Fundamental Aspects and Applications. G. V. Barbosa-Cánovas and Q. H. Zhang, ed. Technomic Publishing Company, Inc., Lancaster, PA

Walstra, P., T. J. Geurts, A. Noomen, A. Jellema, and M. A. J. S. Van Boekel. 1999. Dairy Technology. Principles of milk properties and processes. Marcel Dekker Inc., New York, NY. 